\title{
Priorities: Reflections on an invaluable clinical lesson
}

\author{
Jonathon Broughton, BSC, MD*
}

Keywords: Clinical lessons, medical humanities, memories, priorities

When I started medical school, a professor told the class to "learn one thing from every patient," which I have tried to do. As I approach the end of residency, many of these clinical encounters have started to blur together, but some have become etched into my memory because of the lesson they taught me. It has always amazed me that the complicated map of neurons and synapses of our minds somehow comes together to transcend what would be expected of the constituent parts, creating unique memories and forming a bridge between the physical and metaphysical. I guess I missed the lecture that explained how it works in medical school.

With these memories, smells, sounds, or even words can transport us to a different place and time; sometimes, when I am least expecting it, I get surprised by the smell of leaves in the fall, taking me back to childhood days spent outdoors in southern Ontario, with all the splendour of the maple trees. Other times, the sound of Gord Downie singing "Fiddler's Green" takes me back to an outdoor concert that The Tragically Hip played in Winnipeg, standing beside my then girlfriend, now wife at our first Hip show. Sometimes, even just a single word can spark powerful memories-a word like glioblastoma.

It has been over a year and a half, but I remember the night well. I was on call for the medical intensive care unit (ICU) and was gathering supplies to insert my first transvenous pacer when the familiar sound of the overhead paging system blared: "Code blue, adult, rehab hospital." The rehab hospital is three buildings and multiple stories away from the ICU, which is about as far away as possible in our centre. After running from the unit and silently cursing my stamina, I was directed into a patient room where I asked for the story and tried to catch my breath as I scanned the scene.

I saw a woman younger than myself in a bed, surrounded by her family and nursing staff. A nurse I did not know spoke up: "She's unresponsive! I think she just got some hydromorphone, but her nurse is on break." After quickly assessing the patient and noting her poor respiratory effort, I asked for naloxone to be administered. Her mother identified herself as working in health care, her crying eyes desperately pleading: "Her pupil's blown; she has recurrent glioblastoma. I know what this means! You have to do something. Please do something!"

Glioblastoma. It is just a single word, only 12 letters long, but it is a powerful memory trigger for me, and it takes me right back to that hospital room. Back to the raw emotion of a mother witnessing the beginning of the end of her daughter's life, who by a stroke of misfortune had an incurable tumour in the very organ that made her who she was. Back to the despair of a young physician and new father, who wanted to somehow make it all right and to fix the horrible disease that had already taken too great of a hold; to the gnawing need to do something to impact the pressures inside her skull.

"There isn't another surgical option," said the neurosurgeon, so I explained that there was nothing else to be done, apologized, and explained that the focus would be on comfort, including relieving the horrible headache that the patient had after the naloxone had taken effect. I realized I had just told them the disease was going to win but had provided treatment that interfered with the ability to provide what I promised. I will never forget the look of total, wipe-out loss in her mother's eyes as I left the room.

From *Max Rady College of Health Sciences, University of Manitoba, Winnepeg, MB.

Correspondence to: Dr. Jonathon Broughton, Department of Emergency Medicine, S203 Medical Services Building, 750 Bannatyne Ave. Winnipeg, MB R3E 0W2; Email: umbrougj@myumanitoba.ca

(C) Canadian Association of Emergency Physicians

CJEM 2020;22(1):125-126

DOI 10.1017/cem.2019.373 
The walk back to the unit took much longer than getting to the code; there was no running now. I took a few moments alone in the stairwell to reflect and regain some composure. In our position, we regularly see terrible things, but this case stung; I think this was the only time I have cried in the hospital. I remember thinking about my eight-month-old son sleeping peacefully at home, and it hit me that I took only three days of paternity leave to make up for lost time after a residency transfer. I imagined myself in the shoes of the patient's mother, desperately wishing for a miracle but having the medical knowledge of what was happening to your child - the utter anguish of knowing what comes next.

As it does in this career, the job goes on, and there are missed parties, holidays, and even bedtimes; that night was no exception. There were more procedures, admissions, and codes, all while my son slept at home. Since that night, he has taken his first steps and told me that he loves me for the first time. He is now two years old and notices when I am gone, but, each night that I am away, I can count on getting a video at his bedtime; a quick wave; and him saying "Good night, Daddy, I love you!"

We deal with bad news, tragedy, and death on a regular basis, but the lesson that night was much more visceral and personal than most from my short career in medicine, and that is why it stands out. It was a lesson on setting priorities. For me, that means the little things like singing my son a goodnight song, reading him a book, or answering rapid-fire questions from an inquisitive two-year-old. The beauty of those moments can easily be overlooked, falling behind countless other responsibilities. I am writing this sitting under a painting of a hero of mine, Gord Downie, whose memory and life were also taken by glioblastoma in a cruel twist of fate for a man who spent his life weaving words to both create and become a Canadian legend. As Gord would remind us, this is "no dress rehearsal, this is our life"-take time to savour important moments before they become memories; you never know how many more you will get. 